\title{
EFFECTIVENESS OF TEACHER TRAINING IN TEACHING MATHEMATICS \\ IN SECONDARY LEVEL SCHOOLS
}

\author{
JAGAT KRISHNA POKHAREL
}

Associate Professor, Tribhuvan University, Nepal

\begin{abstract}
This research article investigates the effectiveness of teacher training in the teaching of mathematics on the secondary school level. This study is quantitative as well as qualitative in nature. Some tests are applied to compare the mathematical achievements of the students taught by trained teachers and untrained teachers. Some observations are selected and extracted that helped to support the findings of behavior of trained and untrained teachers in a classroom. This research found that the preparation and the condition of use of instructional materials were poor. In the same way, the initiation of the lesson, a sequence of the subject of matter, students' participation, teacher's activities and conclusion of the lesson were not satisfactory.

KEYWORDS: Trained, Untrained \& Achievements
\end{abstract}

Received: May 23, 2018; Accepted: Jun 13, 2018; Published: Jul 16, 2018 ; Paper Id.: IJESRAUG20182

\section{INTRODUCTION}

The word "mathematics" is derived from an ancient Greek word "Mathema" which developed from the word "Manthanein" which meant "to learn" (Richards, 1965). So mathematics is a process of learning and it is an expression of human mind, concerned chiefly with ideas, processes, and reasoning. Its basic elements are logic and institution, analysis and constructing generality and individually. It is a way of organizing a logical proof.

Teacher training are pre-requisite for quality in the equation. It provides opportunities to teachers for acquire theoretical knowledge of the professional functions and responsibilities of teaching. Teacher training and teacher education which are basic for professional development are major initiatives of teacher development in Nepal.

The basic purpose of training teachers is to increase the efficiency of the school system. In general terms, it can be the achievement of the objectives of the education system. But, such objectives are quite comprehensive, and it is extremely difficult to define in measurable terms. It would be more difficult. However, educational administrators and educators have identified some indicators which help to measure the efficiency of the school system. The achievement of students in the external examination is one of these indicators.

In the context of Nepal, formally teacher training program was started with the establishment of basic teacher training center in 1947 A. D. Later on, the center was changed into National Teacher Training Center in 1956 A. D. (2013 BS) after the implementation of NEPC (2054). In the beginning, the centre provided six month training for SLC teachers and they were appointed as primary teachers. Later the duration of training was increased to 10 months. Secondary teacher training program was established in 1958. After the establishment of Tribhuvan 
University in 1960, faculty of education was also included in the structure of T. U.

Teacher training was made compulsory after the implementation of NESP (1971-1975). All types of training center were integrated to the Tribhuvan University in 1972. Thereafter teachers' training and teacher education, classes were run as credit orientation on all the campuses. The distance education center formally known as Radio Education Teacher Training Project (RETTP) was established in 1978 as the joint venture of GON and US government. The first radio lesson was broadcast on $18^{\text {th }}$ August 1980 by Radio Nepal. It was conducted till 1990. Later, the project was developed into distance education center (DEC) in 1993. National Education Commission (NEC 1992) mentioned clear policy about the vocational teacher's education and training. After the implementation of NEC (1992), TU started three years B. Ed. program in the faculty of Education for teachers for secondary level and introduced one-year B. Ed. program for specialization in different subjects for secondary level education.

The teachers' meaningful preparation of the subject matter and active participation of students are most essential for the effectiveness of teaching. It is possible only when the teacher becomes trained. If not, he can't present well to the students. If the teaching/learning situation is highly dominated by the teacher, it becomes inefficient and ineffective. Certain teaching method may be quite effective for promoting some mathematics topics but may be very ineffective for other topics. It can be better selected only when the teacher is trained by teacher training program.

\section{Objectives}

The main objective of this study was to identify the effectiveness of teacher training in teaching mathematics and to identify the achievement of students taught by trained and untrained teachers.

\section{LITERATURE REVIEW}

Shrestha (1990) did a research on the topic "A Study of the performance and attitude of trained and untrained teachers of Nepal" and concluded that the trained teachers do the better job in teaching and cultivate a more positive attitude towards teaching. Every existence of one or several trained teachers has been found to be instructional, in many ways making modern influences among the staff and the school activities.

A research report "Participatory mathematics teacher training" conducted by CERID (1993) presented various methods of teaching mathematics in secondary schools of Kathmandu valley.

Subedi (2002) in his study, entitled "A study on the effectiveness of Mathematics teacher attitude towards the visually impaired/blind students' achievement in integrated school", concluded that specially trained teachers held significantly better attitude towards the blind students than that untrained teachers. Similarly, the untrained teachers showed their favoritism attitude than that of trained teachers.

Tella (2007) did a study on "The impact of motivation on students' achievement and learning outcomes in mathematics among secondary school students in Nigeria" with an objective to explain learning outcomes in senior secondary mathematics in terms of motivating students towards academic gains in the subject. The two null hypotheses which were tested at 0.05 level of significance of the study were 'there is no significant difference in the impact of motivation on the academic performance of male and female students in mathematics and there is no significant difference of academic performance of highly motivated and slowly motivated students in mathematics achievement test. An ex-post facto design was adopted for the purpose of the study. It comprised all the senior secondary students of Northwest and 
Ibadan South-West local government areas of OYO state of Nigeria as the population of the study. Whereas 450 students were randomly drawn from the selected secondary schools to make a sample of the study. A questionnaire which was divided into two parts was administered for 450 participants to gather data. The first part required the participant's demographic information like as sex, age, class, a name of school etc. From the respondents, they were analyzed by using the inferential statistics. The study concluded that motivation has an impact on academic achievement of secondary school students in mathematics with respect to gender. It also revealed that highly motivated students perform better academic than slowly motivated students.

A comparative study on teaching competency between trained and untrained mathematics teachers of secondary school level (Adhikari, 1997) concluded that the teaching competency of trained teachers was greater than untrained teachers.

Lamichhane (2010) did research work entitled "Effect of teacher training in mathematics achievement at the secondary level. In this study, fifty-six students of class ten of a private school from Tanahun district were selected. $\mathrm{He}$ concluded that the mean achievement score of the students taught with using different training skills was higher than the mean achievement score of the students taught without using different training skills.

\section{METHODOLOGY}

The presented study entitled "Effectiveness of teacher training in teaching mathematics in secondary level schools" was quantitative as well as qualitative in nature. It was designed to examine the effectiveness of teacher training program in mathematics in secondary level. The present research was conducted in Bhaktapur district. A short description was made of strategies and process adopted by teachers while teaching in the classroom. Since the main objective of the study was to compare the achievement of the study by trained and untrained teachers. So the design of the study was quantitative in nature.

\section{Data Analysis}

This study was aimed to investigate the effectiveness of teacher training program in the teaching of mathematics at the secondary level. In this study data were analyzed according to the final results of the mathematics of grade IX which were obtained from the school. Among them, eight involved were trained teachers and others were not trained, teachers.

This part of the study deals with the analysis and interpretation of classroom teaching performance of the lower secondary mathematics teacher of Bhaktapur district. This part also deals with the statistical analysis and interpretation of data obtained from the achievement result of the students from grade IX of the sample students. Data were tabulated and analyzed using mean-variance and one-tailed t-test at the 5\% level of significance.

Table 1

\begin{tabular}{|c|l|c|c|c|}
\hline Group & \multicolumn{1}{|c|}{ Results } & Total no. of Students & Mean & S. D. \\
\hline A & From teacher training program & 64 & 51.42 & 15.11 \\
\hline B & From untrained teacher program & 32 & 34.96 & 6.94 \\
\hline
\end{tabular}

Table 2: One Tailed t Test t0.05 42=1.645

\begin{tabular}{|c|c|c|c|c|c|}
\hline Group & No. & Mean & S. D. & t-Value & Level of Significance One Tailed at 5\% \\
\hline A & 64 & 51.42 & 15.11 & \multirow{2}{*}{7.34} & \\
\hline B & 32 & 34.96 & 6.94 & & \\
\hline
\end{tabular}


From the table no. 2, the statistics achievement scores of two groups A and B are presented with mean, standard deviation with their t-value. The mean score obtained from group A was 51.42 and S. D. 15.11. Similarly, the mean score from group B was 34.96 and S. D. was 6.94. We see that the mean score of group A was higher than the mean score of group B. We see that the mean score of group A was higher than the mean score of Group B and S. D. of group A was also higher than the S. D. of group B.

$$
\text { The t-value } \begin{aligned}
\mathrm{t} 1 & =\frac{\overline{\mathrm{X}}_{1}-\overline{\mathrm{X}}_{2}}{\sqrt{\frac{\mathrm{S}_{1}{ }^{2}}{\mathrm{~N}_{1}}+\frac{\mathrm{S}_{2}{ }^{2}}{\mathrm{~N}_{2}}}} \\
& =\frac{51.42-34.96}{\sqrt{\frac{(15.11)^{2}}{64}+\frac{(6.94)^{2}}{32}}} \\
& =\frac{16.46}{\sqrt{\frac{228.31}{64}+\frac{48.16}{32}}} \\
& =\frac{16.46}{2.24}=7.34
\end{aligned}
$$

i.e. the t-value is 7.34 and tabulated was 1.645 at the $5 \%$ level of significance and 42 degrees of freedom. This shows that $\mathrm{t}$-value was greater than the $\mathrm{t}$-value. It indicates that there was the significant difference between the mean score of result from teacher involved in teacher training program and the mean score of the result from those teachers who were involved in teacher training program. Hence, the result from those teachers involved in teacher training program was better than the result from the teachers who were not involved in teacher training program.

\section{Findings}

The present secondary education system is the accumulated result of basic education project, researches, and innovations conducted in the past for several years in the country. In the comparison of secondary education during the 1950s, the present expansion of basic education has been significantly very high. The provision of increased school facilities, training opportunities for teachers, revision of curriculum and production of quality instructional materials have, to a large extent, contributed to the expansion of secondary schools. Despite these efforts, the quality aspect of basic education has not been a matter of satisfaction to the desired extent.

This study was conducted to investigate the teacher training program and its effect on mathematics achievement at the secondary level. The study established that the teacher training program in mathematics at secondary level was effective.

The mean of the results of the students, from the schools involving trained teachers and schools involving untrained teachers were 51.42 and 34.96 respectively. The score of trained teachers, was higher than the untrained teachers.

This study found that the teacher training program in mathematics at secondary level was highly effective. Classroom observation showed that there was different teaching process of trained and untrained teachers. On the analysis of data, classroom observation found: (i) Achievement of students taught by trained teachers had higher than that achievement of the students taught by untrained teachers; (ii) The physical facilities of most of the schools were very poor; 
(iii) There were lacks of instructional materials in most of the schools; (iv) Trained teachers were also not using their training capability in classroom instruction; (v) Untrained teachers were applying traditional teaching approach, and (vi) Both trained and untrained teachers were undecided about their knowledge of child psychology.

\section{CONCLUSIONS}

The study concluded that the teachers training program in general, were effective in Bhaktapur district. There was much difference between the effectiveness of trained and untrained teachers. Trained teachers were not using their training skills in classroom instruction. The classes were teacher-oriented. Most of the teachers used lecture-method. Making plan was not usual and use of teaching materials was minimal. Both trained and untrained teachers were undecided about their knowledge of child psychology and teachers lacked basic knowledge of how to teach mathematics. To conclude, secondary level trained teachers had a positive attitude than untrained teachers. The students taught by trained and untrained teachers had a much different attitude towards mathematics. The students taught by trained teachers had higher achievement than the students taught by untrained teachers.

\section{REFERENCES}

1. Subedi, D. (2002). A Study on the effectiveness of mathematics teacher attitude towards the visually impaired/blind student achievement in integrated school. Unpublished Master Degree Thesis. T. U.

2. CERID. (1993). Participatory Mathematics Teacher Training. Kathmandu: T. U.

3. Tella, Adedeji. (2007). The Impact of Motivation on Student's Academic Achievement and Learning Outcome in Mathematics among Secondary School Students in Nigeria. Eurasia Journal of Mathematics, Science and Technology Education, 2007, 3 (2), 149-156.

4. Richard, S. (1965). Research in Mathematics Education. NETM.

5. Adhikari, B. (1997). A comparative study on teaching competency between trained and untrained mathematics teacher of secondary level. Unpublished Master Degree Thesis. T. U.

6. Tayeh, Bassam A., et al. "Effects Of Construction Phase Errors On Maintenance Of School Buildings In Gaza Strip."

7. Patra, Bairagi, and Ashok Kumar Mohanty. "Importance Of English For Engineering Students: An Evaluation Of The Prevalent Teaching-Learning System In The Indian Context."

8. Wuyep, Solomon Z., Ambrose A. Zemba, and CJ Jahknwa. "Effects of Precipitation Effectiveness on the Yield of Irish Potato (Solanum Tuberosum) In Jos-Plateau, Nigeria."

9. Shrestha, S. B. (1990). A Study of the performance and attitude of trained and untrained teachers of Nepal. Kathmandu: CERID. T. U.

10. Lamichhane, S. R. (2010). The effect of teacher training in mathematics achievement at secondary level. (A Study in Tanahun District), Kirtipur, Unpublished Master Degree Thesis.

11. Roebuck, F., \& D. Aspy. (1994). Comparative Achievement of the students Taught by Trained and untrained teachers, Paris: UNESCO: International Bureau of Education. Vol. XXIV, p. 411. 
